\title{
latrogenic Ascending Aortic Pseudoaneurysm: A Scarcy Bomb After Coronary Artery Bypass Surgery
}

\author{
Murat Gula, Sinan Incla, Ibrahim Izgu ${ }^{a}$, Emir Kalyoncub, Cengiz Yılmaz \\ a Aksaray University, Department of Cardiology, Training and Research Hospital, Aksaray, Turkey \\ ${ }^{b}$ Aksaray University, Department of Cardiovasculary Surgery, Training and Research Hospital, Aksaray, Turkey \\ ' Aksaray University, Department of Radiology, Training and Research Hospital, Aksaray, Turkey
}

\section{ARTICLE INFO}

Article history:

Submitted: 22. 5. 2020

Revised: 5. 6. 2020

Accepted: 24. 6. 2020

Available online: 22. 10. 2020

Klíčová slova:

Koronární bypass

Pseudoaneurysma

\section{SOUHRN}

Pseudoaneurysma aorty je vzácnou, avšak život ohrožující komplikací, s níž se lze setkat několik měsíců nebo i let po operaci na aortě. I když je kardiochirurgický výkon nejčastější příčinou, mủže k vzniku pseudoaneurysmatu vzácně dojít i po úrazu a infekci. Klinické projevy se mohou pohybovat v rozmezí žádné symptomy až katastrofální výsledek. Průměr a velikost pseudoaneurysmatu aorty se mohou postupem let zvětšovat, což tak může zvyšovat riziko jeho náhlé ruptury a krvácení. Popisujeme prípad pseudoaneurysmatu vzestupné aorty, vzniklého 13 měsíců po koronárním bypassu a úspěšně řešeného chirurgicky. Diagnózu aneurysmatu je nutno stanovit v perioperačním i pooperačním období včas, protože jeho ruptura by měla katastrofální důsledky.

(C) 2020, ČKS.
Keywords:

Coronary artery bypass surgery

Pseudoaneurysm

\begin{abstract}
Aortic pseudoaneurysm is rare but life-threatening complication occurring several months or years after aortic surgery. Although cardiac surgery is the most common cause, it may rarely develop after trauma and infection. Clinical presentation can vary from asymptomatic to catastrophic outcomes. The diameter and size of the aortic pseudoaneurysm may increase over the years, which could consequently increase the risk of sudden rupture and hemorrhage. We present a case of an ascending aortic pseudoaneurysm developed 13 months after coronary artery bypass grafting that were successfully managed by surgical repair. It is essential to diagnose the aneurysm in a timely manner during the perioperative and postoperative periods because rupture of the aneurysm could be catastrophic.
\end{abstract}

\section{Introduction}

Pseudoaneurysm of the aorta (PSA) is a rare but fatal complication of cardiac surgery with a reported incidence is less than $0.5 \%$ in all cardiac surgery cases. ${ }^{1}$ Although cardiac surgery is the most common cause, it may rarely develop after trauma and infection. ${ }^{2}$ Predisposing factors are the dissection of the native aorta, infection, connective tissue disorders, preoperative chronic hypertension, aortic calcification, and blowout of the aortotomy site. ${ }^{3}$ Aortic pseudoaneurysms are usually asymptomatic unless they compress adjacent structures or cause complications. ${ }^{4}$ The diameter and size of the PSA may increase over the years, which could consequently increase the risk of sudden rupture and hemorrhage. ${ }^{5}$ Herein we report a case of a patient with silent aortic pseudoaneurysm who had undergone coronary artery bypass surgery 13 months ago.

\section{Case presentation}

A 73-year-old male patient was admitted to our hospital with chest pain and worsening dyspnea upon exertion. He had a history of hypertension and coronary artery bypass surgery 13 months ago. Physical examination revealed normal vital signs and cardiac auscultation. Electrocardiogram and blood tests (including troponin) were normal. Echocardiography showed an echo-free space which was connected to the aorta with a narrow neck. A computed tomography angiogram confirmed the pseudoaneurysm

Address: Sinan Incl, Aksaray University, Department of Cardiology, Training and Research Hospital, Aksaray, Ankara, 06100 Turkey, e-mail: doktorsinaninci@gmail.com DOI: $10.33678 /$ cor.2020.064 


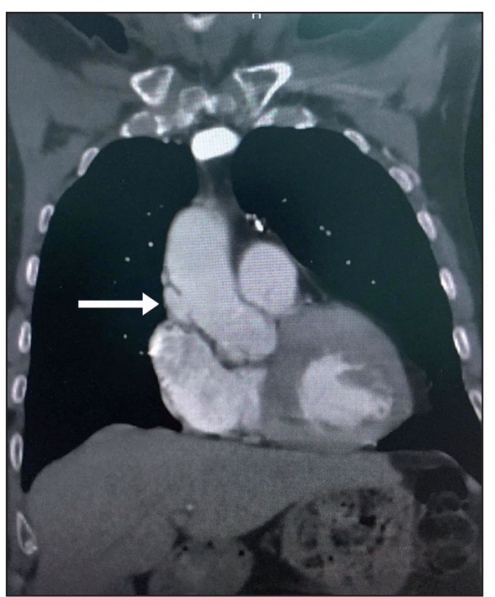

Fig. 1 - Computed tomography angiogram revealed pseudoaneurysm arising from the ascending aorta.

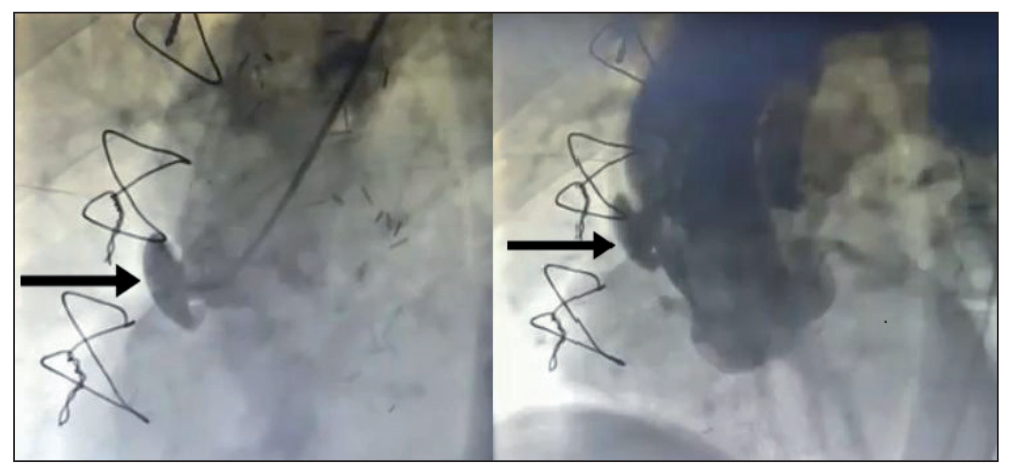

Fig. 2 - Digital subtraction angiographic imaging of the aortic pseudoaneurysm.
$2.3 \times 4.1 \mathrm{~mm}$ size with $13 \mathrm{~mm}$ neck (Fig. 1). For further evaluation coronary angiography and aortography were performed that a pseudoaneurysm formation detected originated proximal of vein graft anastomosis and total occluded circumflex artery graft. Simultaneously digital subtraction angiography was performed. Images of the ascending aorta and pseudoaneurysm were obtained (Fig. 2). The patient was discussed with the heart team which includes; interventional cardiologist, cardiothoracic surgeon and anesthesia staff and surgical treatment were indicated both of pseudoaneurysm repair and coronary artery bypass graft revision. A second vein graft was also placed from the aorta to the obtuse marginal branch of the left circumflex artery. The pseudoaneurysm was dissected and repaired with a patch. Patient's postoperative course was uneventful and he was discharged by the ninth day after surgery. The patient remains asymptomatic under medical follow-up with aortic re-evaluation for six months.

\section{Discussion}

Pseudoaneurysm of the aorta is caused by rupture of at least one layer of the aortic wall, which is surrounded and contained by the remaining aortic walls and adjacent mediastinal structures. ${ }^{6}$ Although the mechanism of the PSA is not fully understood, predisposing factors include connective tissue disorders, advanced age, blunt trauma, dissection of the native aorta, aortic wall degeneration, infection, preoperative hypertension, technical problems with anastomosis.

Most authors report concomitant infection as the main etiological factor, ${ }^{1}$ although the presence of a leak at the site of the previous cannulation was also a major factor in one series. ${ }^{2}$ In our case the patient had no history of obvious mediastinal infection and connective tissue disorder which presented aneurysm within the aortic cannulation site and venous graft anastomosis site so we think anastomosis leak was the most probable cause of aneurysm.

Clinical presentation can be varied from asymptomatic to lethal rupture. The diameter and size of the aortic pseudoaneurysm may increase over the years and symptoms may appear, mainly due to compression of adjacent structures; including chest pain, dyspnea, superior vena cava syndrome or acute coronary syndrome, or right-side heart failure signs. The treatment of PSA is mandatory, irrespective of size and rate of expansion, due to its higher mortality end morbidity. Even though surgical repair is the conventional treatment method, thrombin injection, coil embolization, endovascular grafting andA device occlusion can be alternative treatment.

\section{Learning points}

During long-term follow-up of cardiovascular surgery patients, pseudoaneurysm formation can be detected in initial stage of formation, which makes surgical or endovascular treatments easier and reduces the risk of mortality.

\section{Conflict of interest}

The authors report no financial relationships or conflicts of interest regarding the content herein.

\section{References}

1. Katsumata T, Moorjani N, Vaccari G, Westaby S. Mediastinal false aneurysm after thoracic aortic surgery. Ann Thorac Surg 2000;70:547-552.

2. Atik FA, Navia JL, Svensson LG, et al. Surgical treatment of pseudoaneurysm of the thoracic aorta. J Thorac Cardiovasc Surg 2006;132:379-385.

3. Sabri MN, Henry D, Wechsler AS, et al. Late complications involving the ascending aorta after cardiac surgery: Recognition and management. Am Heart J 1991;121:17791783

4. Erbel R, Alfonso F, Boileau C, et al. Diagnosis and management of aortic dissection: recommendations of the Task Force on Aortic Dissection, European Society of Cardiology. Eur Heart J 2001;22:1642-1681.

4. Mohammadi S, Bonnet N, Leprince P, et al. Reoperation for false aneurysm of the ascending aorta after its prosthetic replacement: Surgical strategy. Ann Thorac Surg 2005;79:147152.

5. Almeida S, Bico P, Almeida AR, et al. latrogenic aortic pseudoaneurysm: A forgotten complication. Rev Port Cardiol 2014;33:113.e1-113.e5. 